\title{
Liming and Mineral Fertilization of Acid Soils in Maize Crop within the Savannah of Southwestern of Democratic Republic of Congo
}

\author{
Jean Pierre Kabongo Tshiabukole ${ }^{1,2^{*}}$, Gertrude Pongi Khonde ${ }^{1}$, André Matondo Phongo1, \\ Nlandu Ngoma1, Roger Kizungu Vumilia1,3, Amand Mbuya Kankolongo ${ }^{1,2}$ \\ ${ }^{1}$ Institut National pour l'Etude et la Recherche Agronomiques/Mvuazi, Mvuazi, Democratic Republic of the Congo \\ ${ }^{2}$ Université Pédagogique Nationale, Kinshasa, Democratic Republic of the Congo \\ ${ }^{3}$ Université de Kinshasa, Kinshasa, Democratic Republic of the Congo \\ Email: ^jpkabon2005@gmail.com
}

How to cite this paper: Tshiabukole, J.P.K., Khonde, G.P., Phongo, A.M., Ngoma, N., Vumilia, R.K. and Kankolongo, A.M. (2022) Liming and Mineral Fertilization of Acid Soils in Maize Crop within the Savannah of Southwestern of Democratic Republic of Congo. Open Access Library Journal, 9: e8412.

https://doi.org/10.4236/oalib.1108412

Received: January 31, 2022

Accepted: March 1, 2022

Published: March 4, 2022

Copyright $\odot 2022$ by author(s) and Open Access Library Inc.

This work is licensed under the Creative Commons Attribution International License (CC BY 4.0).

http://creativecommons.org/licenses/by/4.0/

\begin{abstract}
This paper mainly investigated the interactive effects between liming and mineral fertilization in the acid soils in maize crop of the south-west of the DRC, two factors including liming as main factor, at two levels (with and without) and three levels of mineral fertilizers (controls without fertilizer, NPK 12-24-12, NPK12-24-12 + Urea 46\%) as secondary factor, were used in a split-plot design with three replications. The results showed that the soils neither limed nor fertilized considerably reduced $(p<0.05)$ the agronomic performance of maize. However the interactions between liming and mineral fertilizers have significantly influenced $(\mathrm{p}<0.05)$ and positively the growth parameters (height of the insertion) and flowering (day at $50 \%$ male flowering and female flowering), and therefore a significant difference $(\mathrm{p}<0.05)$ for grain yield, harvest rate and appearance of the ears. Liming combined to mineral fertilization, in the proportions required for maize cultivation, improved around $50 \%$ of the production per unit area of maize gain in the acidic soils of Mvuazi.
\end{abstract}

\section{Subject Areas \\ Agricultural Science}

\section{Keywords}

Liming, Mineral Fertilizer, Acidic Soil, Zea mays, INERA

\section{Introduction}

In Africa under the tropics, maize is grown on 94 million hectares whose acid 
soils occupy $29 \%$ of the arable lands [1]. On these lands, maize yields are reduced due to Aluminum (Al) or Manganese (Mn) toxicity, or Calcium (Ca), Magnesium (Mg), Phosphorus (P), and Molybdenum (Mo) deficiencies [2] [3] [4], low basal saturation, altered biological activity, and other acidity induced soil fertility and plant nutrition problems [5]. These soils generally have a low $\mathrm{pH}$, so-called acidic. The characteristics mentioned above inhibit root development, leading to low absorption of water and nutrients and consequently to low yields. These problems are particularly acute in humid tropical regions where soils have been greatly weathered by the elements [6]. As the soil becomes more and more acidic, particularly when the Hydrogen potential $(\mathrm{pH})$ drops below 4.5 , it becomes increasingly difficult to produce food crops [6] because the supply of most plant nutrients decreases while aluminum and some micronutrients become soluble and toxic to plants [7].

Soil acidity affects about $50 \%$ of potentially arable land worldwide, particularly in the humid tropics [8]. However, the level of this acidity, as well as its associated impact on soil fertility and crop productivity, should intensify in a changing climate [9] [10] [11].

The ideal soil $\mathrm{pH}$ for many crops is slightly acidic, between 6.0 and 7.0 [12] because all nutrients are in well-balanced proportions in this range [13].

Agricultural lime $\left(\mathrm{Ca}(\mathrm{OH})_{2}\right)$ is the main way to improve soil acidity [14] because it has strong acid-neutralizing ability, which can effectively remove the existing acid. Liming increases nutrient uptake, stimulates biological activity and reduces heavy metal toxicity.

The use of lime as well as integrated nutrient management is therefore recommended to increase the phytoactivity of essential nutrients and improve other fertility constraints induced by acidity [5] [15] [16]. Favorable crop responses to liming appear to be primarily caused by aluminum deactivation [6].

The South western of the Democratic Republic of Congo (DRC) is a very important agricultural area, with a typically high level of soil acidity and very high rainfall. Acidity-induced soil fertility problems associated with traditionally minimal use of mineral fertilizers are often blamed for low levels of crop productivity [17].

Since lime makes minerals available to plants, liming without fertilizer application leads to a decline in soil fertility which could lead to serious production problems [6]. Therefore, the application of fertilizers to correct the nutritional constraints caused by acidity would be necessary to improve agricultural productivity.

The objective of this work is to evaluate the interactive effect of liming and mineral fertilization on the performance of growth and yield of maize in acid soils of southwestern DRC.

\section{Materials and Method}

The trial was conducted on acid soil at the INERA Mvuazi research center dur- 
ing cropping season A 2019-2020. Mvuazi is located at $14^{\circ} 54^{\prime}$ East longitude and $5^{\circ} 21^{\prime}$ South latitude, at an altitude of $470 \mathrm{~m}$. The soil of Mvuazi belongs to the Sudano-Guinean climatic zone of type AW4 following the Köppen classification. This soil is characterized by low organic matter content and low water retention capacity, resulting in low nitrogen availability [18] [19] and Orthic ferral soil type (Table 1). According to the soil acidity scale of [20], with a $\mathrm{pH}$ of 5.76, the soils of Mvuazi are classified as acidic.

Using a split-plot device with three replications involving two factors, the main factor of which was the liming at two levels (Liming and without $=$ Nill) and the secondary factor was the application of mineral fertilizers at three levels (controls without fertilizer, NPK12-24-12 and NPK12-24-12 + Urea (46\%). The NPK was applied at the sowing by a method called microdosing at $100 \mathrm{~kg} / \mathrm{ha}$. The microdosing consisted of a localized application of NPK fertilizer ( $3 \mathrm{~g} / \mathrm{hill})$ i.e. $160 \mathrm{~kg} / \mathrm{ha}$ and Urea $(1.125 \mathrm{~g} / \mathrm{hill})$ i.e. $60 \mathrm{~kg} / \mathrm{ha}$ [21] Urea was applied in two halves respectively on the 15 th day and on the 30 th day after sowing. $800 \mathrm{~kg} / \mathrm{ha}$ was applied according to the Arvalis protocol [22] for ploughing.

The SAMARU maize variety (obtained by INERA and sensitive to low soil nitrogen levels) serving as a test plant was sown at spacings of $0.75 \mathrm{~m} \times 0.50 \mathrm{~m}$ at the rate of 2 grains per hill in individual plots of $2.5 \mathrm{~m} \times 5 \mathrm{Mr}$.

The cultural care consisted of weeding and cleaning the paths and the surroundings of the experimental field. Figure 1 presents the experimental device used in the test.

Lime treatments (limed): $\mathrm{T} 0=$ Control without mineral fertilizer

$$
\begin{aligned}
& \mathrm{T} 1=\mathrm{NPK} \\
& \mathrm{T} 2=\mathrm{NPK}+\text { Urea }
\end{aligned}
$$

Nill treatments (not limed): $\mathrm{T} 3=$ Control without mineral fertilizer

$$
\begin{aligned}
& \mathrm{T} 4=\mathrm{NPK} \\
& \mathrm{T} 5=\mathrm{NPK}+\text { Urea }
\end{aligned}
$$

The data was collected on the basis of observations made on the growth variables, namely: days at 50\% male flowering (Poll), days at 50\% female flowering (Silk), interval between male flowering and female flowering (ASI), plant height (Plant height), height of upper ear insertion (Ear height), percentage of root

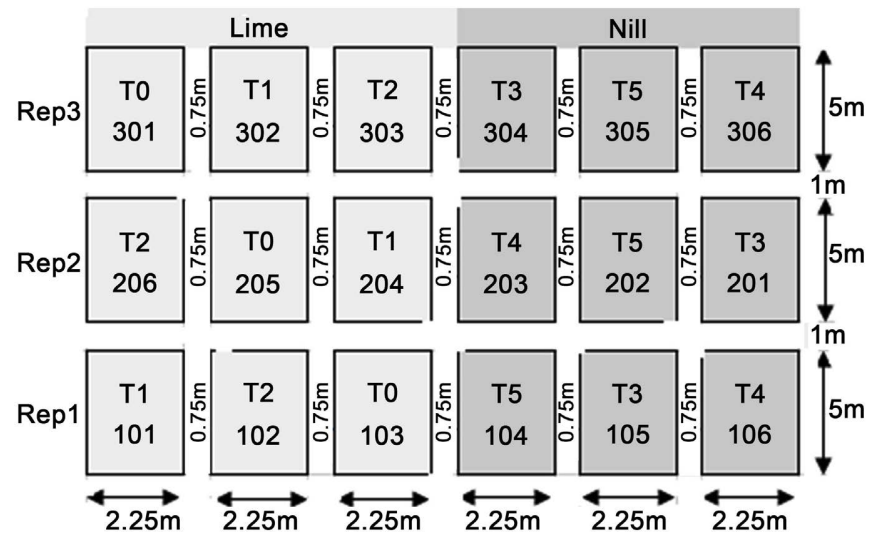

Figure 1. Experimental device. 
Table 1. General physico-chemical properties of Mvuazi soil.

\begin{tabular}{|c|c|c|c|c|c|c|c|c|c|}
\hline $\begin{array}{l}\text { Parameters } \\
\text { (unit) }\end{array}$ & Sol pH & P1 (ppm) & $\mathrm{K}(\mathrm{ppm})$ & $\mathrm{Ca}(\mathrm{ppm})$ & $\mathrm{Mg}(\mathrm{ppm})$ & $\mathrm{Mn}(\mathrm{ppm})$ & $S(p p m)$ & $\mathrm{Cu}(\mathrm{ppm})$ & B (ppm) \\
\hline Results & 5.76 & 14 & 105 & 1505 & 229 & 55 & 23 & 12.30 & 0.21 \\
\hline Bottom guide & 6.00 & 30 & 268 & 1651 & 165 & 100 & 20 & 2.00 & 1.00 \\
\hline Top guide & 7.00 & 100 & 537 & 2064 & 264 & 250 & 200 & 10.00 & 2.00 \\
\hline $\begin{array}{c}\text { Paramètres } \\
\text { (unité) }\end{array}$ & $\mathrm{Zn}(\mathrm{ppm})$ & $\mathrm{Na}(\mathrm{ppm})$ & $\mathrm{Fe}(\mathrm{ppm})$ & CEC (meq/100g) & $\mathrm{OC}(\mathrm{meq} / 100 \mathrm{~g})$ & Silt (\%) & Sand (\%) & Clay (\%) & N (\%) \\
\hline Résultats & 7.98 & 47 & 194 & 13.76 & 4.07 & 13 & 49 & 39 & 0.21 \\
\hline Guide Bas & 4.00 & 0 & 150 & 15.00 & & 30 & 30 & 20 & 0.20 \\
\hline Guide Haut & 20.00 & 158 & 350 & 30.00 & & 50 & 55 & 55 & 0.50 \\
\hline
\end{tabular}

lodging (Root lodg), percentage of stem lodging (stem lodg) and productivity variables as percentage of plants harvested (Plant harv), plant aspect (plant aspct), ear aspect (Ear aspect), grain yield (Yield), ear rot percentage (Ear rot).

Aspects of seedlings and ears were rated on a rating scale of 1 to 5 where $1=$ excellent, $2=$ good, $3=$ fairly good, $4=$ not good and $5=$ bad [23].

\section{Statistical Analyzes}

The data collected were subjected to analysis of variance using the agricolae package of the $\mathrm{R}$ statistical software following the general linear model $\left(\operatorname{aov}\left(y \sim f a c t 11^{\star}\right.\right.$ fact $\left.\left.1+r e p\right)\right)$ to determine the difference between the means of the treatments. The means of the treatments which presented significant differences were separated by the post-hoc test of the least significant difference (LSD) at the threshold of 5\%. A principal component analysis (PCA) using the R package FactoMineR was carried out to establish the correlations between the studied variables.

\section{Results and Discussion}

After processing and analyzing the data collected during and at the end of the trial, two groups of results were identified according to the development phases of the maize plants.

\subsection{Effects of Lime and Mineral Fertilizers on Maize Growth and Flowering Stage}

Table 2 below presents the performance results of maize during the growth phase under the conditions of liming, mineral fertilization and their combination. The analyzes of variance carried out on the data from the growth and flowering stage of maize showed very significant effects $(p<0.01)$ of mineral fertilizers at $50 \%$ male flowering and significant effects $(p<0.05)$ for $50 \%$ of female flowering. However, the effects of liming and fertilizer were less significant $(\mathrm{p}=$ 0.0929 ) for the flowering interval. The number of days at $50 \%$ male flowering varied between 52 and 57 days respectively for $\mathrm{T} 2$ and $\mathrm{T} 3$. While the number of 
Table 2. Effects of liming and mineral fertilizers on maize growth under Mvuazi conditions.

\begin{tabular}{|c|c|c|c|c|c|c|c|}
\hline Liming & Fertilizers & Poll & Silk & ASI & Plant eight $(\mathrm{cm})$ & Ear eught (cm) & Root lodg. (\%) \\
\hline & Control & $55.66 \pm 2.08 \mathrm{ab}$ & $56.33 \pm 2.08 a$ & $0.66 \pm 1.15 b$ & $185.58 \pm 2.09 a$ & $97.41 \pm 7.96 b$ & $26.37 \pm 12.12 \mathrm{a}$ \\
\hline \multirow[t]{3}{*}{ Lime } & NPK & $54.66 \pm 0.57 \mathrm{ab}$ & $56.66 \pm 1.52 b$ & $2.00 \pm 1.73 \mathrm{ab}$ & $187.31 \pm 17.41 \mathrm{a}$ & $104.25 \pm 10.53 \mathrm{ab}$ & $28.32 \pm 9.27 a$ \\
\hline & $\mathrm{NKP}+$ Urea & $52.00 \pm 1.00 c$ & $53.33 \pm 1.52 b$ & $1.33 \pm 0.57 \mathrm{ab}$ & $198.08 \pm 8.30 \mathrm{a}$ & $119.33 \pm 11.76 a$ & $22.18 \pm 13.79 a$ \\
\hline & Control & $57.00 \pm 1.73 a$ & $60.33 \pm 2.88 b$ & $3.33 \pm 1.15 a$ & $180.25 \pm 21.68 a$ & $97.75 \pm 10.39 b$ & $39.62 \pm 11.99 a$ \\
\hline \multirow[t]{2}{*}{ Nill } & NPK & $54.33 \pm 1.15 b c$ & $56.33 \pm 1.15 b$ & $2.00 \pm 2.00 \mathrm{ab}$ & $187.50 \pm 4.75 a$ & $109.33 \pm 5.44 \mathrm{ab}$ & $41.45 \pm 14.54 a$ \\
\hline & $\mathrm{NKP}+$ Urea & $53.66 \pm 1.15 b c$ & $54.33 \pm 1.15 b$ & $0.66 \pm 1.15 b$ & $188.50 \pm 15.59 a$ & $109.00 \pm 8.52 \mathrm{ab}$ & $40.62 \pm 20.15 a$ \\
\hline \multicolumn{2}{|c|}{ Lime Effect } & 0.20857 & 0.1031 & 0.2839 & 0.479 & 0.7229 & $0.0248^{\star}$ \\
\hline \multicolumn{2}{|c|}{ Fertilizer effect } & $0.00917^{\star *}$ & $0.0112^{\star}$ & 0.2259 & 0.618 & $0.0481^{\star}$ & 0.9316 \\
\hline \multicolumn{2}{|c|}{ Lime ${ }^{\star}$ fertilizer effect } & 0.552 & 0.0683 . & 0.0929. & 0.743 & 0.675 & 0.9931 \\
\hline \multicolumn{2}{|c|}{$\mathrm{CV}(\%)$} & 2.5873 & 3.3 & 75.31 & 7.55 & 9 & 36.85 \\
\hline \multicolumn{2}{|c|}{$\operatorname{LSD}(\mathrm{p}<0.05)$} & 2.53 & 3.33 & 2.25 & 25.52 & 17.17 & 21.919 \\
\hline
\end{tabular}

Signif. codes: 0 “***” 0.001 “**” 0.01 “*” 0.05 “” 0.1 “” 1 .

days at $50 \%$ female flowering varied between 53.3 and 60.3 days corresponding to the T2 and T3 treatments. The interval between male and female flowering varied between 0.6 and 3.3 days respectively for T0, T5 and T3. No significant difference $(p>0.05)$ was observed between the averages of the plants height, while a significant difference $(p<0.05)$ was observed for the height of insertion of the upper ear with positive fertilizers effects for both levels of liming. The height of the insertion of the upper ear varied between $119.3 \mathrm{~cm}$ for T2 and 97.4 $\mathrm{cm}$ for T0. Lime application had significantly influenced $(\mathrm{p}<0.05)$ root lodging. The smallest root lodging rate (22.18) was recorded in $\mathrm{T} 2$, while the highest rate (41.45) was recorded in T4.

\subsection{Effects of Liming and Mineral Fertilizers on Maize Yield Parameters}

Analysis of variance on yield data (Table 3 ) showed a significant difference ( $\mathrm{p}<$ 0.05 ) between treatments on stem lodging. The application of mineral fertilizers had a significant effect $(\mathrm{p}=0.03152)$ on stem lodging. The highest stem lodging rate was recorded in Q5 (22.09) and the lowest rate was recorded in Q3. From the point of view of plant appearance, significant effects of liming and NPK + Urea fertilizers were observed. The best aspect of the plant $(1=$ excellent $)$ was recorded at T2 and the worst at T3 (control without fertilizer). In general, the application of NPK + Urea fertilizers influenced significantly $(\mathrm{p}=0.0045)$ the yield. The average yield varied between $0.14 \mathrm{~kg} / \mathrm{m}^{2}$ and $0.33 \mathrm{~kg} / \mathrm{m}^{2}$ respectively for T3 and T5. It appears from these analyzes that lime and fertilizers did not significantly influence $(p>0.05)$ the appearance of the ear, ear rot, or the rate of harvested plants. 
Table 3. Effects of liming and mineral fertilizers on maize productivity under mvuazi conditions.

\begin{tabular}{|c|c|c|c|c|c|c|c|}
\hline Liming & Fertilizers & Stem lodg. (\%) & Plant asp. (1-5) & Yield $\left(\mathrm{kg} / \mathrm{m}^{2}\right)$ & Ear rot (1-5) & Ear asp. (1-5) & Plant harv. (\%) \\
\hline & Control & $16.42 \pm 17.59 a b$ & $1.66 \pm 0.57 b$ & $0.20 \pm 0.020 \mathrm{bc}$ & $1.66 \pm 2.08 \mathrm{a}$ & $1.66 \pm 0.57 a$ & $76.84 \pm 20.21 \mathrm{a}$ \\
\hline \multirow[t]{3}{*}{ Lime } & NPK & $10.47 \pm 6.99 \mathrm{bd}$ & $1.33 \pm 0.57 b$ & $0.20 \pm 0.08 b c$ & $1.66 \pm 0.57 \mathrm{a}$ & $1.33 \pm 0.57 a$ & $64.09 \pm 5.25 a$ \\
\hline & NKP + Urea & $8.60 \pm 4.55 b c$ & $1.00 \pm 0.00 b$ & $0.29 \pm 0.038 a$ & $1.33 \pm 1.52 \mathrm{a}$ & $1.33 \pm 0.57 a$ & $67.24 \pm 3.92 \mathrm{a}$ \\
\hline & Control & $3.17 \pm 2.74 c$ & $2.66 \pm 0.57 a$ & $0.14 \pm 0.095 c$ & $1.00 \pm 1.00 \mathrm{a}$ & $1.66 \pm 1.15 \mathrm{a}$ & $55.77 \pm 17.88 \mathrm{a}$ \\
\hline \multirow[t]{2}{*}{ Nill } & NPK & $11.15 \pm 6.33 \mathrm{abc}$ & $1.66 \pm 0.57 b$ & $0.266 \pm 0.055 \mathrm{ab}$ & $1.33 \pm 1.52 \mathrm{a}$ & $1.66 \pm 1.15 \mathrm{a}$ & $69.99 \pm 7.43 a$ \\
\hline & NKP + Urea & $22.09 \pm 11.19 a$ & $1.33 \pm 0.57 b$ & $0.33 \pm 0.058 a$ & $1.33 \pm 1.52 \mathrm{a}$ & $1.33 \pm 0.57 a$ & $79.26 \pm 13.62 \mathrm{a}$ \\
\hline \multicolumn{2}{|c|}{ Lime Effect } & 0.91857 & $0.0454^{*}$ & 0.61663 & 0.49894 & 0.768 & 0.873 \\
\hline \multicolumn{2}{|c|}{ Fertilizer Effect } & $0.03152^{\star}$ & $0.0392^{*}$ & $0.00452^{\star *}$ & 0.94783 & 0.895 & 0.424 \\
\hline \multicolumn{2}{|c|}{ Lime $^{\star}$ Fertilizer effect } & 0.07844 & 0.2925 & 0.07893 . & 0.7806 & 0.718 & 0.113 \\
\hline \multicolumn{2}{|c|}{ CV (\%) } & 51.9 & 32.41 & 20.94 & 72.81 & 51.89 & 19.696 \\
\hline \multicolumn{2}{|c|}{$\operatorname{LSD}(p<0.05)$} & 11.181 & 0.938 & 0.0911 & 1.817 & 1.399 & 24.377 \\
\hline
\end{tabular}

Signif. codes: 0 “***” 0.001 “**” 0.01 “*” 0.05 “” 0.1 “” 1 .

\section{Principal Component Analysis}

The PCA was carried out on 12 active variables characterizing the variables on the basis of the data of the combination of the factors. More than $58 \%$ of the variability is represented on the plane formed by two axes Dim1 and Dim2. Only four dimensions had an eigenvalue greater than 1 . The factorial map of the variables (Figure 2) shows that the two dimensions are characterized by strong correlations between the variables.

Dim1 benefits strong contributions from growth and yield-related variables, including male and female flowering and flowering interval, plant height, height of ear insertion, and plant appearance. This indicates that the yield is greater when the intervals between male and female flowering are short $(\mathrm{ASI}<3)$ and the harvest rate is high. Otherwise an excellent aspect induces a good production. As for fertilization, we observe that the combination of lime, NPK and Urea promotes good productivity (Figure 3). Correlations are negative between flowering interval and yield, as are days at $50 \%$ male and female flowering.

Dim2 is characterized by the rate of root lodging, stem lodging, ear rot rate and ear appearance. Strong positive correlations between root lodging and rot have been observed, however these parameters are negatively correlated with stem lodging (Figure 2). The individual factorial map shows that a significant dispersion of the treatments (with lime and without lime) was observed around two axes. The Lime + NPK + Urea combinations remain favorable for a higher yield (Figure 3 ).

At the end of the verification of the hypothesis according to which liming without fertilizer application leads to a drop in soil fertility which could lead to 
serious production problems, it emerges from the results of this work that treatments without lime presented the values of variables lower than those of lime treatments. Like the conclusions of research made by Harter [6], it should be said that the results of this work corroborate with those of Anetor and Ezekiel [14].

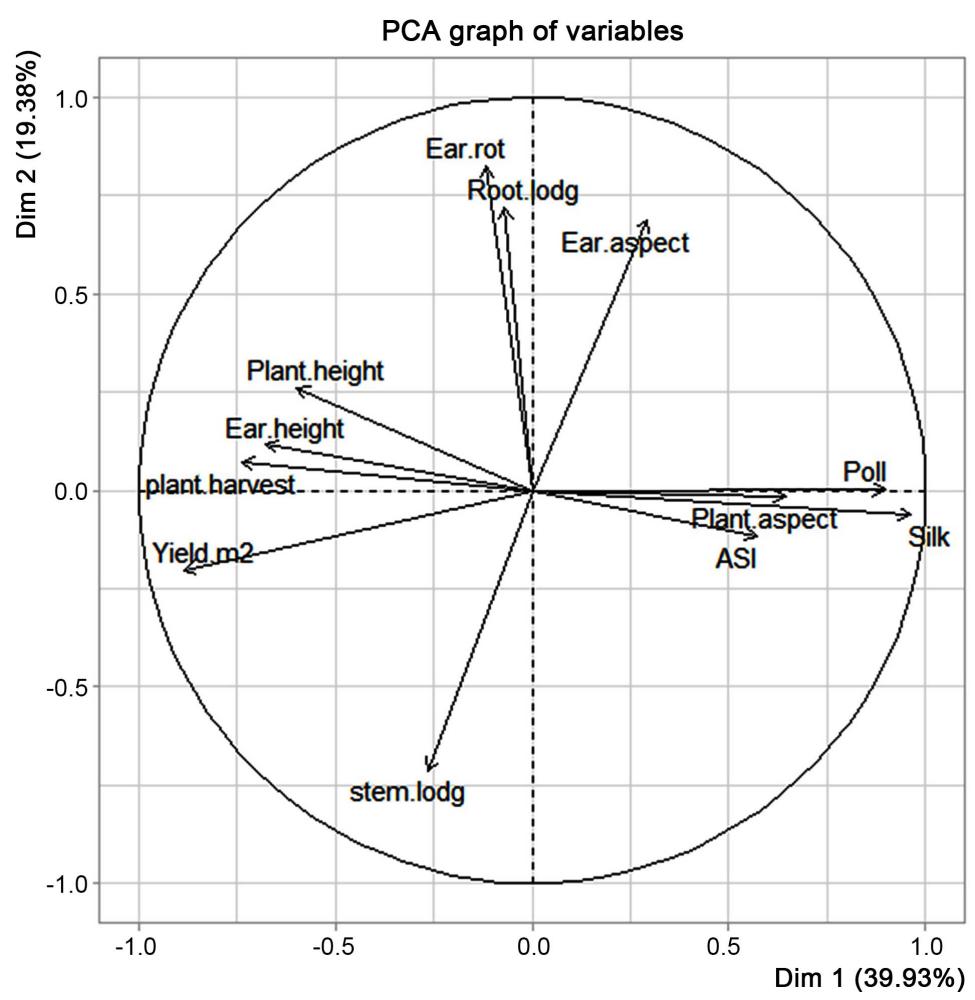

Figure 2. Factorial map of the variables studied.

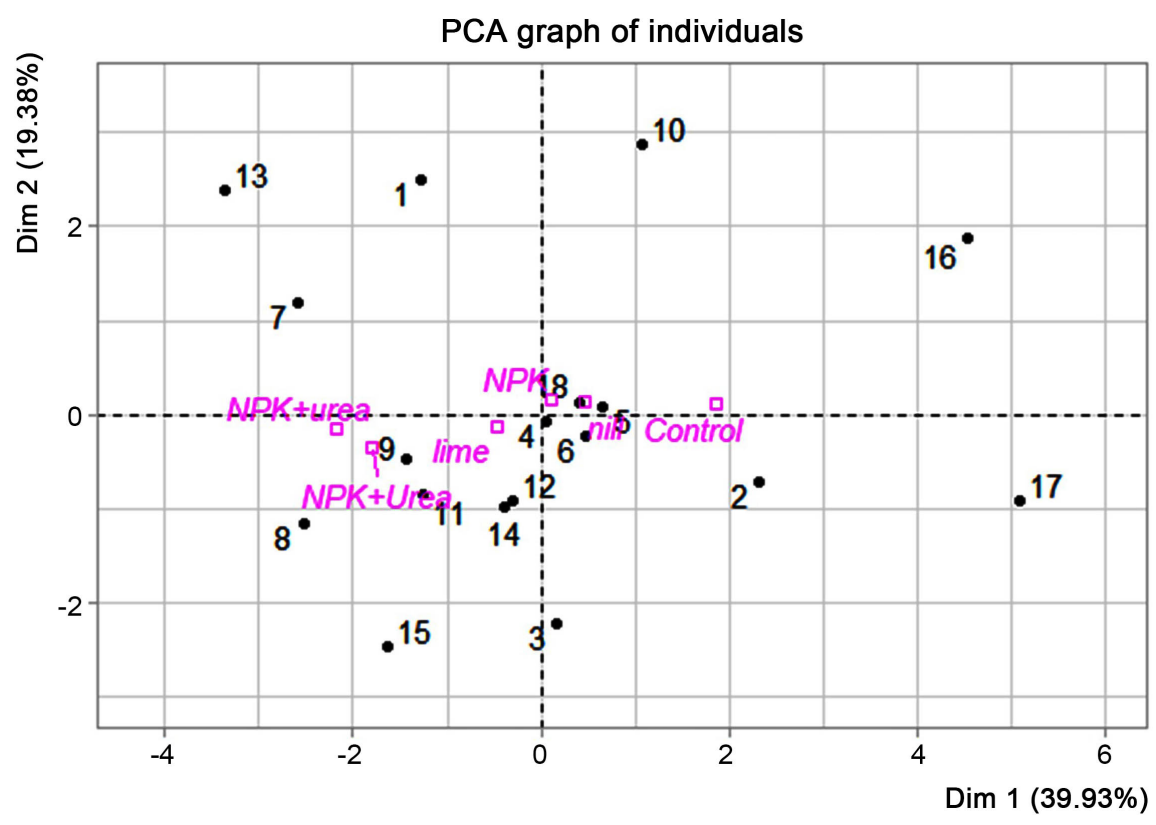

Figure 3. Factorial map of observed individuals. 
This situation can be explained by the fact that in general, the increase in calcium content and soil $\mathrm{pH}$ stimulates microbial growth, which affects the availability of nitrogen, as noted, as well as on that of some other nutrients. Conversely, increased microbial growth can lead to faster loss of organic matter in the soil, which is generally considered negative.

The low productivity observed in treatments without lime or fertilizers is dependent on the presence of soluble aluminum in the soil, which leads to toxicity responsible for a drop in yield. As a result, a $\mathrm{pH}$ above 5.5 will be sought in most situations, especially for barley, corn and beet crops [24].

Based on the results of maize growth analysis, many laboratory studies have determined that the first visible damage caused by aluminum is the inhibition of root elongation [25] [26] [27] [28] [29]. Plant height should therefore be reduced in maize plants sown without; such is therefore the case of T3 in this work.

Tshiabukole et al. [23] showed that intervals between male and female flowering greater than 3 days indicated the susceptibility of maize to stress. However, it was found in this work that the control plants (T3) had average ASI values greater than 3 days. Thus this treatment favored a reduction in grain yield of nearly $50 \%$.

Regarding the grain yield, it was observed in this work that the treatments combining lime and fertilizers had significantly improved the yield of the fertilizer treatment. Thus the results of this test confirm the hypotheses put forward by Harter [6]. But the variations were greater, around $50 \%$, when no fertilizer was applied. Thé et al. [30] have shown that in maize, soil acidity can lead to yield reductions of around 67\%, however Welker et al. [31] asserted that the negative effect of the aluminum toxicity of soils on grain yield is between 46 and $73 \%$ depending on the locality.

\section{Conclusion}

The purpose of this work was to evaluate the interactive effect of liming and mineral fertilization on the growth and yield performance of maize. Indeed it results from this work some relevant observations such as the soils of Mvuazi being acidic are characterized by a weak growth and production of the corn. Lime amendments alone in these soils are not sufficient to improve the agronomic performance of maize. A combined application of lime and mineral fertilizers (NPK and Urea) in the proportions corresponding to the needs of the plant is necessary to restore the soil in one growing season and improve maize production by almost $50 \%$.

\section{Acknowledgements}

We thank all those who agreed to participate actively in this study as well as their establishments and affiliated institutions.

\section{Conflicts of Interest}

The authors declare no conflicts of interest. 


\section{References}

[1] Eswaran, H., Reich, P. and Beigroth, F. (1997) Global Distribution of Soils with Acidity. In: Monitz, A.C., Ed., Plant Soil Interaction at Low pH, Brazilian Soil Science Society, Campines Brazil, 159-164.

[2] Aldrich, S.R., Scott, W.O. and Leng, E.R. (1975) In Modern Corn Production. A \& L Publication, Champain.

[3] Borrero, J.C., Pandey, S., Ceballos, H., Mangnavaca, R. and Bahia, A.F.C. (1995) Genetic Variances for Tolerance to Soil Acidity in Tropical Maize Population. Maydica, 40, 283-288.

[4] Clark, R.B. (1997) Effect of Aluminium on Growth and Mineral Elements of Al-Tolerant Corn. Plant and Soil, 47, 653-662. https://doi.org/10.1007/BF00011034

[5] Patiram (1991) Liming of Acid Soils and Crop Production in Sikkim. Journal of Hill Research, 4, 6-12

[6] Harter, R.D. (2002) Acid Soils of the Tropics. University of New Hampshire, New Hampshire.

[7] Sanchez, P.A. and Logan, T.J. (1992) Myths and Science about the Chemistry and Fertility of Soils in the Tropics. In: Lal, R. and Sanchez, P.A., Eds., Myths and Science of Soils of the Tropics, Soil Science Society of America Special Publication No. 29, Soil Science Society of America Special Publication, Madison, 35-46. https://doi.org/10.2136/sssaspecpub29.c3

[8] Von Uexküll, H.R. and Mutert, E. (1995) Global Extent, Development and Economic Impact of Acid Soils. Plant and Soil, 171, 1-15.

https://doi.org/10.1007/BF00009558

[9] Oh, N.-H. and Richter, D.D (2004) Soil Acidification Induced by Elevated Atmospheric $\mathrm{CO}_{2}$. Global Change Biology, 10, 1936-1946. https://doi.org/10.1111/j.1365-2486.2004.00864.x

[10] Manoj-Kumar (2011) North East India: Soil and Water Management Imperatives for Food Security in a Changing Climate. Current Science, 101, 1119.

[11] Manoj-Kumar (2011) Evidences, Projections and Potential Impacts of Climate Change on Food Production in Northeast India. Indian Journal of Hill Farming, 24, $1-10$.

[12] The Pennsylvania State University (1995) Soil Acidity and Aglime.

[13] Bierman, P.M. and Rosen, C.J. (2005) Nutrient Cycling and Maintaining Soil Fertility in Fruit and Vegetable Crop Systems. University of Minesota, Minneapolis.

[14] Anetor, M.O. and Ezekiel, A.A. (2007) Lime Effectiveness of Some Fertilizers in a Tropical Acid Alfisol. University of Ibadan, Ibadan.

[15] Haynes, R.J. (1984) Lime and Phosphate in the Soil-Plant System. Advances in Agronomy, 37, 249-315. https://doi.org/10.1016/S0065-2113(08)60456-3

[16] Manoj-Kumar, Khan, M.H., Singh, P., Ngachan, S.V., Rajkhowa, D.J., Kumar, A. and Devi, M.H. (2012) Variable Lime Requirement Based on Differences in Organic Matter Content of Iso-Acidic Soils. Indian Journal of Hill Farm, 25, 26-30.

[17] Tshiabukole, K., Khonde, P., Muku, M., Vumilia, K., Lunekua, K. and Kankolongo, M. (2016) Influence of Climate Variability on Seasonal Rainfall Patterns in South-Western DR Congo. Open Access Library Journal, 3, Article No. e2952.

[18] Tshiabukole, J.P.K. (2018) Evaluation de la sensibilité aux stress hydriques du maïs (Zea mays L.) cultivé dans la savane du Sud-Ouest de la RD Congo, cas de Mvuazi. Thèse de Doctorat, Faculté des Sciences Agronomiques, Département de Phyto- 
technie, Université Pédagogique Nationale, RD Congo, 162.

[19] Fakorede, M.A.B., Badu-Apraku, B., Kamara, A.Y., Menkir, A. and Ajala, S.O. (2003) Maize Revolution in West and Central Africa: An Overview. Proceedings of a Regional Maize Workshop. IITA-Cotonou, Republic of Benin, 14-18 May 2001, 3-15.

[20] Global-SWISS (2005) Protocol de mesures de pH du sol. 1-4

[21] Mbuya, A.K., Kabongo, J.P.T., Pongi, G.K., Matondo, A.P., Nlandu, N., Kombozi, G.B., Tshimbombo, C.J., Mulumba, G.B., Kaboko, J.K., Masengu, T.T., Nkongolo, J.M. and Kizungu, R.V. (2020) Effect of Double Planting Density and Smaller Fertilization Rates on Grain Yield of Quality Protein Maize in a Clay-Sandysoil in Mvuazi. Open Access Library Journal, 7, Article No. e6632.

https://doi.org/10.4236/oalib.1106632

[22] Arvalis (2019).

https://www.arvalis-infos.fr/en-chaulage-d-entretien-les-produits-a-action-lente-suf fisent-@/view-19995-arvarticle.html

[23] Kabongo, T., Pongi, K., Mumba, D., Kizungu, V., Mbuya, K. and Nkongolo, K. (2016) Evaluation of Maize Sensitivity to Drought in Southwestern Savannah Area of DR. Congo. African Journal of Agricultural Science and Technology (AJAST), 4, 812-817.

[24] Agriculture et Territories (2015).

https://bourgognefranchecomte.chambres-agriculture.fr/fileadmin/user upload/Nationa 1/FAL commun/publications/Bourgogne-Franche-Comte/CDA71/07 2015 Chaulage.p df

[25] Horst, W.J., Püsched, A.K. and Schmoll, N. (1997) Induction Callose Formation Is a Sensitive Marker for Genotypic Aluminium Sensitivity in Maize. Plant and Soil, 192, 23-30. https://doi.org/10.1023/A:1004204120863

[26] Kollmeier, M., Felle, H.H. and Horst, W.J. (2000) Genotypical Differences in the Distal Part of the Transition Zone. Is Reduced Basipetal Auxin Flow Involved in Inhibition of Root Elongation by Aluminium? Plant Physiology, 122, 945-956. https://doi.org/10.1104/pp.122.3.945

[27] Llugany, M., Massot, N., Wissemeier, H.A., Posscheriender, C., Horst, W.J. and Barcelo, J. (1994) Aluminium Tolerance of Maize Cultivars as Assessed by Callose Production and Root Elongation. Zeitschrift für Pflanzenernährung und Bodenkunde, 157, 447-451. https://doi.org/10.1002/jpln.19941570609

[28] Sivaguru, M. and Horst, W.J. (1998) The Distal Part of the Transition Zone Is the Most Aluminium Sensitive Apical Root Zone of Zea mays L. Plant Physiology, 116, 155-163. https://doi.org/10.1104/pp.116.1.155

[29] Wissemeier, A.H., Klotz, F. and Horst, W.J. (1987) Aluminium Induced Callose Synthesis in Roots of Soybean (Glycine max L.). Journal of Plant Physiology, 129, 487-492. https://doi.org/10.1016/S0176-1617(87)80012-3

[30] Thé, C., Mafouasson, H.A., Calba, H., Mbouemboue, P., Zonkeng, C. and Horst, W.J. (2006) Identification de groupes hétérotiques pour la tolérance du maïs (Zea mays L.) aux sols acides des tropiques. Cahiers Agricultures, 15, 337-346.

[31] Welcker, C., Thé, C., De Leon, C., Parentoni, S.N., Bernal, J., Félicité, J., Zonkeng, C., Salazar, F., Narro, L. and Horst, W.J. (2005) Heterosis and Combining Ability for Adaptation of Maize to Acid Soils: Implication for Future Breeding Strategies. Crop Science, 42, 2405-2413. https://doi.org/10.2135/cropsci2004.0606 